\title{
Structure and dynamics of phytoplankton in an Amazon lake, Brazil
}

\author{
Ise de Goreth Silva ${ }^{1}$, Ariadne do Nascimento Moura ${ }^{2 *}$, Enio Wocyli Dantas ${ }^{3} \&$ Maria do Carmo \\ Bittencourt-Oliveira ${ }^{4}$ \\ 1. Universidade Federal de Roraima, Departamento de Biologia, Av. Ene Garcez, 2413, Aeroporto, 69304-000, Boa \\ Vista, RR, Brazil. \\ 2. Universidade Federal Rural de Pernambuco, Departamento de Biologia, Área de Botânica, R. Dom Manoel de \\ Medeiros, s/n, Dois Irmãos, 52171-030, Recife, PE, Brazil; ariadne@db.ufrpe.br \\ 3. Universidade Estadual da Paraíba, Centro de Ciências Biológicas e Sociais Aplicadas, Rua Monsenhor Walfredo Leal, \\ 487, Tambiá, 58020-540, João Pessoa, PB, Brazil. \\ 4. Escola Superior de Agricultura Luiz de Queiroz, Departamento de Ciências Biológicas, Av. Pádua Dias, 11, C. Postal \\ 9, 13418-900, Piracicaba, SP, Brazil. \\ * Corresponding author.
}

Received 04-VIII-2009. C Corrected 20-III-2010. Accepted 26-IV-2010.

\begin{abstract}
Natural lake systems represent important reservoirs for residential water supply, fish production, recreational activities and enjoyment of their natural beauty. Nevertheless, human impacts may affect their health status resulting in degradation and loss of biodiversity. The aim of the present study was to obtain data on the health status of a natural lake located in an indigenous reservation in the Brazilian Amazon, using the phytoplankton community changes along the rainy (June) and dry (November) seasons of 2006. We collected water (temperature, $\mathrm{pH}$, Secchi depth and conductivity) and phytoplankton samples from the subsurface, middle of the water column, and approximately $30 \mathrm{~cm}$ above the bottom, over 24-hour sampling periods, from a central station in the lake. Samples taken from biotic and abiotic variables were correlated using canonical correspondence analysis (CCA). Results showed that the lake exhibited high temperatures in both seasons, and showed thermal stratification only during the rainy season. Dissolved oxygen exhibited a clinograde pattern in the rainy season and high oxygen in the hypolimnion in the dry season. In the rainy season, the water near the bottom was acidic, turbid and had a greater concentration of phosphorus. Dissolved oxygen, conductivity, $\mathrm{pH}$, nitrite, total phosphorus and total dissolved phosphorus exhibited diel variations in the rainy season, whereas water temperature, dissolved oxygen, total nitrogen and total dissolved phosphorus exhibited significant differences between hours of the day in the dry season. The phytoplankton was represented by 39 taxa, and Chlorophyta showed the greatest species richness, totaling 25 taxa. Among Chlorophyta, desmids were the most diverse, accounting 52\%. Bacillariophyta (nine species) was the second most diverse group. Cyanophyta was represented by three species, including Merismopedia tenuissima, the most abundant taxon. Despite the occurrence of taxa that indicate organic pollution, their biomass and frequency indicate that the system is not currently threatened. Lake Caracaranã is an oligotrophic system, with low algal density and isolated blooming episodes due to its shallow depth. Rev. Biol. Trop. 58 (4): 1421-1436. Epub 2010 December 01.
\end{abstract}

Keywords: Chlorophyta, Cyanophyta, diel variation, oligotrophic system, seasonal variation, tropical lake, Brazil.

The state of Roraima is located in the Brazilian Amazon and has a hydrographic basin with a large variety of aquatic systems, which are distinguished by their combination of physical, chemical and biological characteristics.
Some lakes located in depressions of the Boa Vista Formation are generally small and isolated from large and medium-sized rivers. In these areas, lakes generally have clear waters, which may be either occupied by different species of 
aquatic macrophytes and filamentous algae or deprived of vegetation (Filho et al. 1997).

Lake systems in the savannas of the state of Roraima are important reservoirs for the residential water supply, fish production, recreational activities and enjoyment of their natural beauty. However, their existence is increasingly compromised by the human influence, such as landfills for real estate purposes and contamination from agriculture runoff. This affects the health status of ecosystems and produces negative effects, such as degradation and the loss of biodiversity.

Environmental changes affect algal structuring. The species best adapted to the new ecological situation become more abundant and there is a reorganization of the structure and dynamics of the community. Phytoplankton is a good indicator of changes in aquatic environments due to its rapid response within short time intervals, especially with regard to reproductive processes. Certain organisms are bioindicators of climatic, physical and chemical conditions as well as trophic state and biological pressure, such as predation (Reynolds 1998, Reynolds et al. 2002). These taxa can help researchers gain a better understanding of current processes and design intervention strategies for improving the health status of ecosystems.

A number of studies have been carried out on the floodplains of hydrographic basins in Argentina, Mexico, the United States, Spain, Japan and Colombia, addressing the structure and dynamics of the phytoplankton community and the main effects of variations in water level on the composition and functioning of these communities (Izaguirre et al. 2001, Takano et al. 2001; Maberly et al. 2002; Komárková \& Tavera 2003; Rodrigo et al. 2003; Domitrovic 2003; Schagerl \& Oduor 2003; Kangurt et al. 2003; Roozen et al. 2003; Schemel et al. 2004; Walks \& Cyr 2004; Pinilla 2006). The results of these studies demonstrate that cyanobacteria and Chlorophyta are important groups and often dominant groups in such environments.

In the Brazilian Amazon, studies addressing the phytoplankton community began in the 1940s, with the pioneering work of Grönblad (1945), followed by ten studies published in the 1960s, 70s and 80s. Investigations in the region began to intensify in the 1990 s with studies by Bittencourt-Oliveira (1993), Menezes et al. (1995), Sophia \& Dias (1996), Huszar (1996a), Sophia \& Huszar (1996), Keppeler et al. (1999a, 1999b), Lopes \& Bicudo (2003), Roland (2000) and Souza et al. (2007). These taxonomic studies demonstrate that Chlorophyta is an important group in the phycological flora, with Desmidiaceae the most representative due to the acidic characteristics of the waters in Amazonian ecosystems.

Subsequent studies were carried out with a focus on phytoplankton ecology with assessments of biomass, density, primary production and hydrological variables (Huszar 1996b; Huszar \& Reynolds 1997; Huszar et al. 1998; Ibañez 1998; Kristiansen \& Menezes 1998; Huszar 2000; Dellamano-Oliveira et al. 2003). These studies demonstrate that temporal and spatial patterns of the structure of the phytoplankton community may be influenced by hydrological pulses.

The aim of the present study was to analyze the structure and dynamics of a phytoplankton community as a tool for gathering knowledge on the health status of aquatic systems. For this purpose, a natural lake in the Brazilian Amazon was studied during a circadian cycle in two distinct seasonal periods.

\section{MATERIALS AND METHODS}

The present study was carried out in Lake Caracaranã (03 $50^{\circ} 41^{\prime \prime} \mathrm{N}$ and 59 $\left.46^{\prime} 52^{\prime \prime} \mathrm{W}\right)$, which is located in the depression of the Boa Vista Formation and distributed among savanna areas in the Northeastern region of the State de Roraima (Brazilian Amazon). The lake has a circumference of approximately $3.8 \mathrm{~km}$ (Filho et al. 1997) and has clear waters, with a seasonal variation in depth ranging from 2.0 to $6.0 \mathrm{~m}$ in the dry and rainy seasons, respectively. Lake Caracaranã is colonized by a dense community of immersed and submersed aquatic macrophytes. Based on the Köppen-Geiger 
classification, the State of Roraima pertains to the A climatic group (humid tropical). The rainfall pattern is represented by two rather distinct periods: a rainy season (April to September) and a dry season (October to March) (Roraima Environment and Technology Foundation, 1994). Mean monthly rainfall during the study period ranged from $7 \mathrm{~mm}$ (February) to $643.7 \mathrm{~mm}$ (June) and temperature ranged from $26.4^{\circ} \mathrm{C}$ (July) to $29.4^{\circ} \mathrm{C}$ (November) (Brazilian National Meteorology Institute, 2006).

Water samples for nutrient analysis and the investigation of the phytoplankton community (taxonomic and density studies) were collected at the same time and with two repetitions with a vertical van Dorn bottle with a $3 \mathrm{~L}$ of capacity at a central station in the lake over 24-hour sampling periods from the subsurface, middle of the water column and approximately $30 \mathrm{~cm}$ above the bottom. Samples $(\mathrm{n}=2)$ were taken at four-hour intervals for a total of seven collections per period (Noon, 4 pm, 8 pm, $12 \mathrm{am}, 4 \mathrm{am}, 8 \mathrm{am}$ and midnight). Sampling was performed once in the rainy season (June 2006) and dry season (November 2006).

Abiotic variables were determined in situ and included water temperature and dissolved oxygen (Schott Glaswerke Mainz, handylab OX1); conductivity and total dissolved solids (TSD) (Schott Glaswerke Mainz, handylab LF1); turbidity (Hanna Instruments, HI 93703); $\mathrm{pH}$ (Digimed, DMPH-2) and water transparency (Secchi disc $25 \mathrm{~cm}$ in diameter). For the determination of dissolved and total nutrients, water aliquots were placed in $300 \mathrm{ml}$ polyethylene flasks and kept refrigerated until analysis. Samples were filtered through $47 \mathrm{~mm}$ AP20 glass multi-pore filters for the determination of dissolved nutrients. Non-filtered aliquots were used for the determination of total nutrients. Analysis to determine concentrations of total nitrogen $(\mu \mathrm{mol} . \mathrm{TN} / \mathrm{L})$, nitrite $\left(\mu \mathrm{mol} . \mathrm{N}-\mathrm{NO}_{2} / \mathrm{L}\right)$ and nitrate $\left(\mu\right.$ mol.N-NO $\left.\mathrm{N}_{3} / \mathrm{L}\right)$ followed the procedures described by Valderrama (1981), Mackereth et al. (1978) and Golterman et al. (1978), respectively. Total phosphorus ( $\mu \mathrm{mol}$. $\mathrm{TP} / \mathrm{L}$ ) and total dissolved phosphorus ( $\mu \mathrm{mol}$. TDP/L) were determined following Valderrama
(1981). Orthophosphate $\left(\mu \mathrm{mol} . \mathrm{P}-\mathrm{PO}_{4} / \mathrm{L}\right)$ was determined following Strickland \& Parsons (1965).

The Carlson Trophic State Index adapted by Toledo Jr. et al. (1983) for tropical regions was used for the trophic characterization of the ecosystem. Calculations were based on values of chlorophyll $a$, Secchi depth, total phosphorus and orthophosphate. Ultra-oligotrophic $(\leq 20)$, oligotrophic (21 to 40), mesotrophic (41 to 50), eutrophic (51 to 60$)$ and hypertrophic $(\geq 61)$ conditions were then determined (Kratzer \& Brezonik 1981).

Samples for taxonomic and density analyzes $(n=2)$ were preserved in acetic Lugol's solution. Morphometric features of the reproductive and vegetative phases were analyzed under a Zeiss microscope (model Axioskop) equipped with a light chamber, photographic camera and ocular with a measurement grid. Those for which identification was not possible were considered phytoflagellates. The samples were added to the collection at the Professor Vasconcelos Sobrinho Herbarium of the Universidade Federal Rural de Pernambuco.

Densities (individuals per microliter) were estimated based on the method described by Utermöhl (1958), using an inverted microscope (Zeiss, Axiovert). Organism counts were carried out with two repetitions for each depth sampled; the values are presented as the mean of the repetitions. The calculations were carried out based on the method described by Villafaiñe \& Reid (1995). Dominant and abundant species were determined based on the concepts described by Lobo \& Leighton (1986), for which a dominant species is that which surpasses $50 \%$ of the total phytoplankton density and an abundant species is that with a density value greater than the mean value of the community. The values are presented as the mean of the repetitions.

Analysis of variance (ANOVA) was used with a 5\% level of significance to determine the degree of temporal variation (time of day and season), seasonal period and spatial variation (depth). Tukey's multiple comparison tests was used to identify where differences were 
expressed in time and space. Analyses were performed using the Statistica 2004 software program (StatSoft, Inc., Tulsa, OK, USA). The Shannon-Wiener diversity index (H', bits/ind) was calculated (Shannon \& Weaver 1963); Evenness was assessed based on the $\mathrm{H}^{\prime}$ of the Shannon-Wiener index. Canonical correspondence analysis (CCA) was used to determine correlations between biotic and abiotic variables. Only abundant and dominant species were considered for the analysis. The PC-ORD version 4.14 for Windows was used for the statistical analysis (McCune \& Mefford 1999).

\section{RESULTS}

Lake Caracaranã has high light availability, with transparency values of $2.90 \mathrm{~m}$ in the rainy season and $2.00 \mathrm{~m}$ in the dry season. High water temperatures occurred in both seasons. Thermal stratification occurred in the rainy season and there was no stratification in the dry season. Dissolved oxygen exhibited a clinograde pattern in the rainy season and high oxygenation in the hypolimnion in the dry season. Vertical variations were also recorded for $\mathrm{pH}$, turbidity and total phosphorus in the rainy season, with the water near the sediment more acidic, turbid and with a greater concentration of phosphorus (Table 1). The other parameters did not exhibit statistically significant vertical differences ( $p>0.05$ ) (Table 2). Based on physiochemical characteristics, Lake Caracaranã is classified as an ultra-oligotrophic to oligotrophic system (Table 1).

Dissolved oxygen, conductivity, $\mathrm{pH}$, nitrite, total phosphorus and total dissolved phosphorus exhibited significant diel variations in the rainy season, whereas water temperature, dissolved oxygen, total nitrogen and total dissolved phosphorus exhibited significant differences between times of the day in the dry season $(\mathrm{p}<0.05)($ Table 2$)$.

Significant seasonal differences were found for the abiotic variables, except water temperature and orthophosphate $(\mathrm{p}>0.05)$ (Table 2). Conductivity, turbidity, total nitrogen, nitrite and total dissolved phosphorus values were greater in the rainy season, whereas dissolved oxygen, $\mathrm{pH}$, nitrate and total phosphorus were greater in the dry season (Table 1).

The phytoplankton comprised 39 taxa (Table 3), with five identified on the genus level, 33 species and one group of phytoflagellates. Chlorophyta contributed the greatest species richness, totaling 25 taxa. Among the Chlorophyta, the desmids were the most diverse, accounting for $52 \%$ of the taxa of this division. The genus with the greatest number of species was Staurastrum (six species). Bacillariophyta was the second most diverse division, with nine species. Cyanophyta was represented by just three species.

Low phytoplankton densities were encountered throughout the study, with densities ranging from 202 individuals $/ \mathrm{mL}$ (at the bottom, at $8 \mathrm{am}$ in both seasons) to $1135 \mathrm{ind} / \mathrm{mL}$ (in the middle of the water column at $8 \mathrm{pm}$ in the rainy season) (Table 3). No significant variations in phytoplankton density were found between times in either the dry or the rainy season $(p>0.05)$. Total density exhibited significant vertical differences $(\mathrm{p}<0.001)$ in both seasons $(\mathrm{F}=17.063$ in the dry season; $\mathrm{F}=18.531$ in the rainy season), with significantly lower values at the subsurface $(\mathrm{p}<0.01)$.

Cyanophyta were dominant $(73.41 \%$ of the total density) in the rainy season, whereas Chlorophyta were dominant (73.08\%) in the dry season (Figure 1A and 1B). Cyanophyta was abundant in $100 \%$ of the samples; Chlorophyta in $95.24 \%$; Bacillariophyta in $42.86 \%$; and phytoflagellates were abundant in just $2.38 \%$. Thirteen taxa were classified as abundant, with the predominance of: Merismopedia tenuissima Lemmermann (50.66\%), Monoraphidium griffithii (Berkeley) Komárková-Legnerová (12.97\%), Botryococcus terribilis J. Komárek \& P. Marvan (9.23\%) and Sphaerocystis schroeteri Chodat (5.65\%), (Table 3).

Diel variations in the Shannon-Wiener diversity index ranged from 1.05 to 2.91 in the rainy season and 2.66 to 3.57 in the dry season. The phytoplankton community exhibited low evenness $(0.35$ to 0.75$)$ in the rainy season and high evenness ( 0.70 to 0.87$)$ in the dry season. 


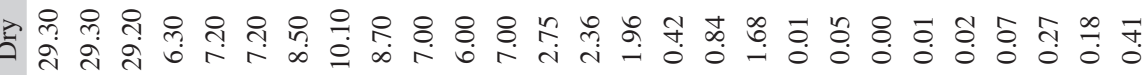

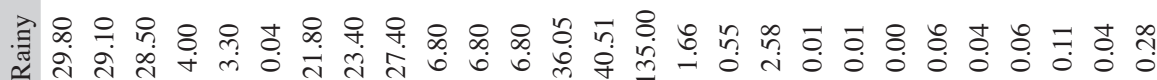

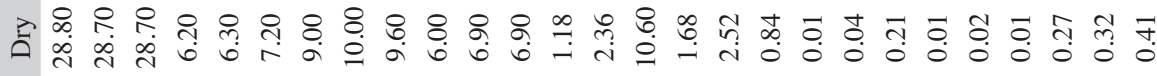

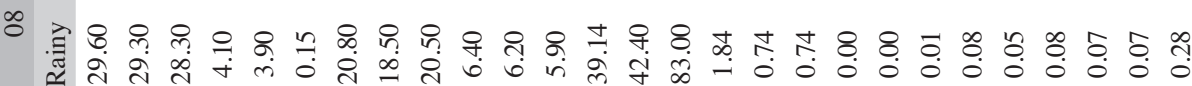

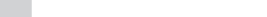

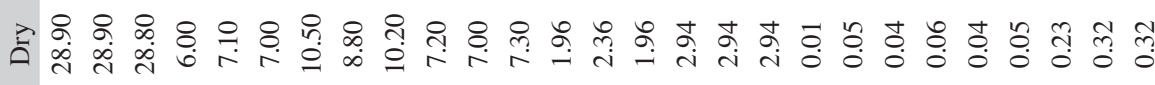

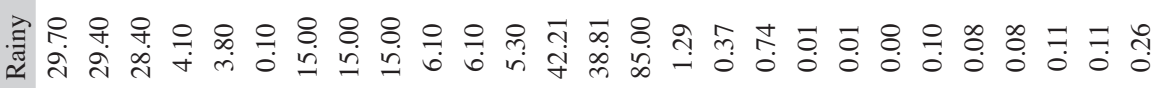

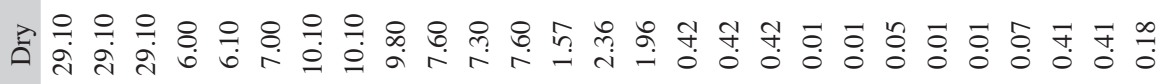

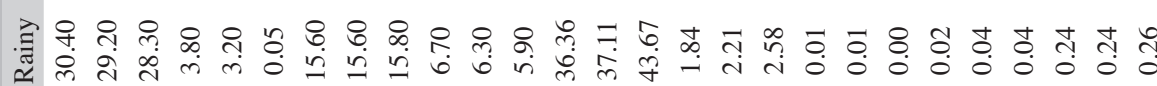

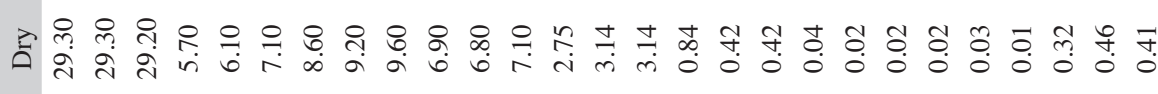

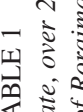

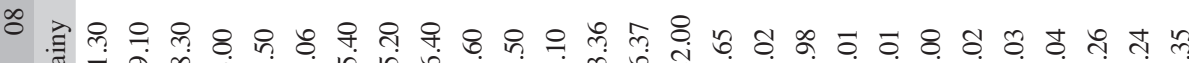
๙

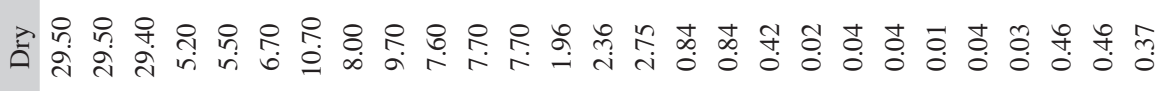
t) ๙

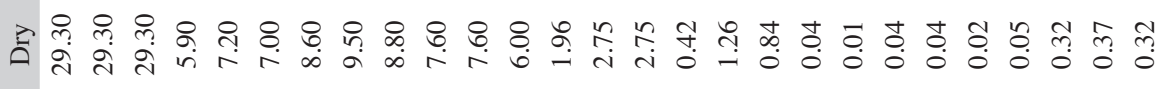
辛 )

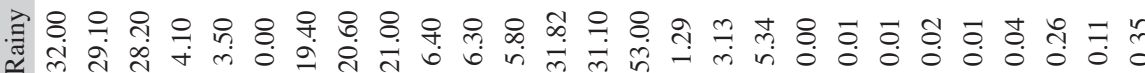

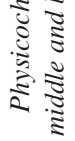

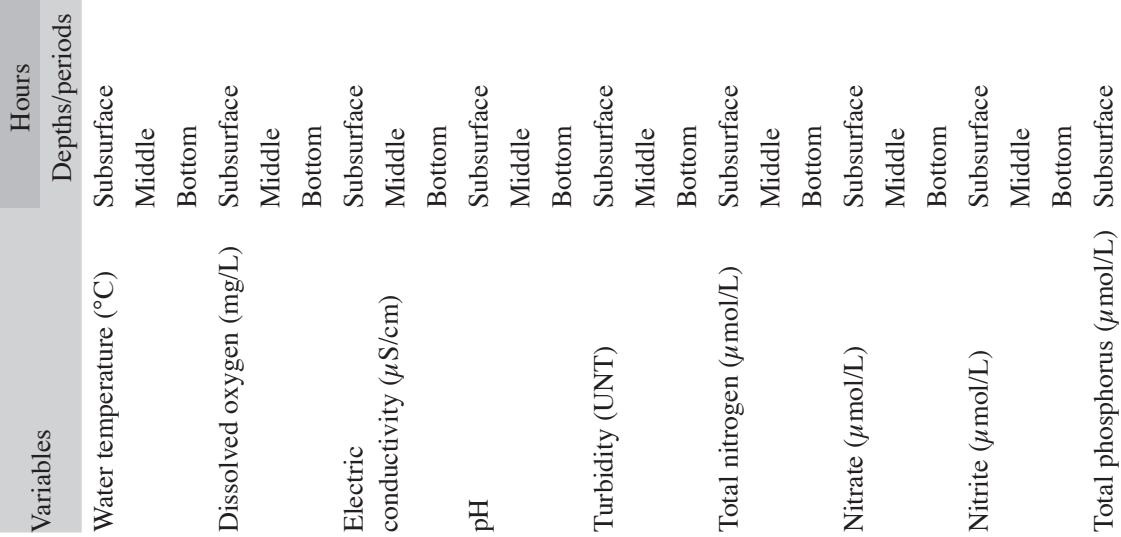




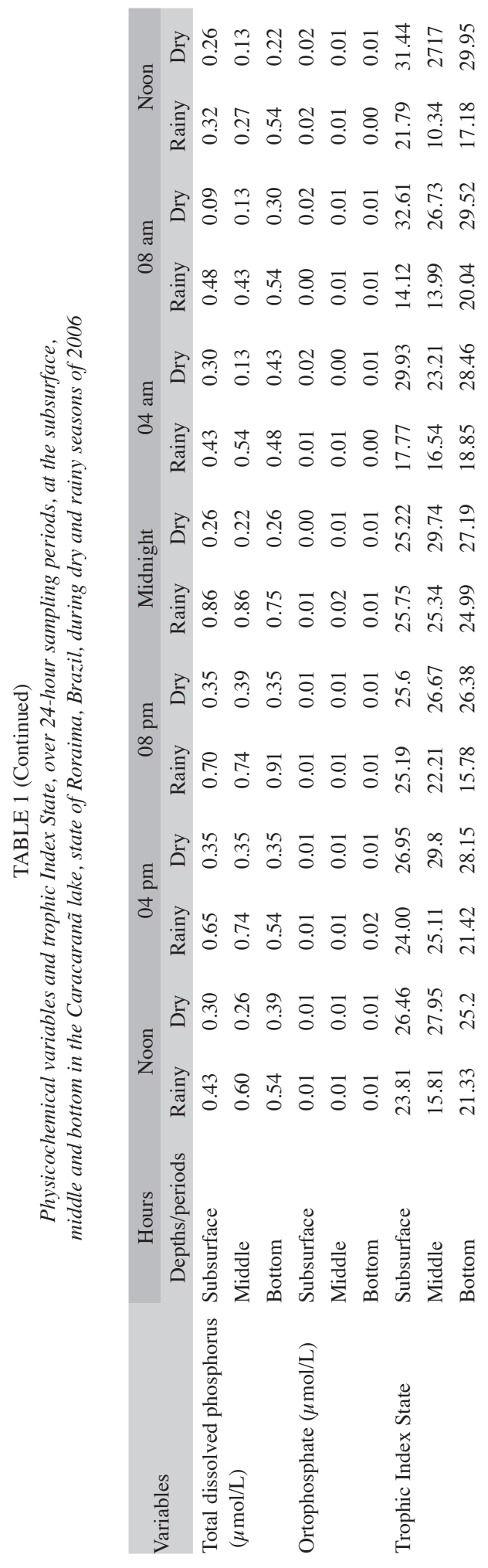

Low evenness was associated with the predominance of Merismopedia tenuissima, which had higher density in the rainy season than the dry season.

The results of the canonical correspondence analysis (CCA) are displayed in Table 4 and Figure 2. The Monte Carlo test demonstrated that Axes 1 and 2 achieved statistical significance $(\mathrm{p}<0.05)$, indicating correlations between the environmental variables and the phytoplankton community. The values of Axes 1 and 2 explained $54.2 \%$ of the variability in the data. Pearson's correlation coefficient for the axes indicated a strong correlation between species and environmental variables.

On Axis 1, there was a separation of the sample units between the rainy and dry seasons. An analysis of the intra-set correlation coefficient reveals that conductivity, turbidity and total dissolved phosphorus were associated with the rainy season, whereas dissolved oxygen, $\mathrm{pH}$, nitrate and total phosphorus were associated with the dry season. Merismopedia tenuissima and phytoflagellates were the most important taxa on this axis and associated with the rainy season. The following species were associated with the dry season: Botryococcus terribilis, Cosmarium contractum, Monoraphidium griffithii, Sphaerocystis schroeteri, Staurastrum nudibrachiatum and Tabellaria sp.

On Axis 2, there was vertical separation of the samples in both seasons. This axis revealed diel variation in the rainy season. Based on the canonical coefficient, the most important variables were dissolved oxygen and total phosphorus. The following species were associated with this axis: Aulacoseira ambigua, Cylindrospermopsis raciborskii, Pinnularia maior and Surirella sp.

\section{DISCUSSION}

Studies carried out in the Amazon have demonstrated that thermal behavior is a determinant factor in the daily variety of a number of limnological variables, whether in the reduction of dissolved oxygen or in the accumulation 
TABLE 2

Variance values between depths, hours and seasons (dry and rainy/2006) for abiotic variables studied at the Caracaranã lake-Roraima, Brazil. Significant values in bold type $(p<0.05)$

\begin{tabular}{|c|c|c|c|c|c|c|c|}
\hline \multirow{2}{*}{ Variables } & \multirow{2}{*}{ Season } & \multicolumn{2}{|c|}{ Depths } & \multicolumn{2}{|c|}{ Hours } & \multicolumn{2}{|c|}{ Seasons } \\
\hline & & $\mathrm{F}$ & $\mathrm{p}$ & $\mathrm{F}$ & $\mathrm{p}$ & $\mathrm{F}$ & $\mathrm{p}$ \\
\hline \multirow[t]{2}{*}{ Water temperature $\left({ }^{\circ} \mathrm{C}\right)$} & Rainy & 24.818 & $<0.001$ & 0.613 & 0.718 & \multirow{2}{*}{0.590} & \multirow{2}{*}{0.547} \\
\hline & Dry & 9.000 & 0.004 & 182.714 & $<0.001$ & & \\
\hline \multirow[t]{2}{*}{ Dissolved oxygen $(\mathrm{mg} / \mathrm{L})$} & Rainy & 2038.037 & $<0.001$ & 3.044 & 0.048 & \multirow{2}{*}{30.832} & \multirow{2}{*}{$<0.001$} \\
\hline & Dry & 20.452 & $<0.001$ & 3.612 & 0.028 & & \\
\hline \multirow[t]{2}{*}{ Electric conductivity $(\mu \mathrm{S} / \mathrm{cm})$} & Rainy & 2.344 & 0.137 & 26.549 & $<0.001$ & \multirow{2}{*}{131.415} & \multirow{2}{*}{$<0.001$} \\
\hline & Dry & 0.025 & 0.976 & 0.653 & 0.690 & & \\
\hline \multirow[t]{2}{*}{$\mathrm{pH}$} & Rainy & 22.257 & $<0.001$ & 10.037 & 0.001 & \multirow{2}{*}{31.829} & \multirow{2}{*}{$<0.001$} \\
\hline & Dry & 0.051 & 0.951 & 1.872 & 0.167 & & \\
\hline \multirow[t]{2}{*}{ Turbity (UNT) } & Rainy & 10.951 & 0.002 & 1.204 & 0.368 & \multirow{2}{*}{30.958} & \multirow{2}{*}{$<0.001$} \\
\hline & Dry & 1.191 & 0.338 & 0.708 & 0.651 & & \\
\hline \multirow[t]{2}{*}{ Total nitrogen $(\mu \mathrm{mol} / \mathrm{L})$} & Rainy & 0.845 & 0.543 & 1.704 & 0.203 & \multirow{2}{*}{4.568} & \multirow{2}{*}{0.033} \\
\hline & Dry & 0.632 & 0.553 & 11.026 & 0.001 & & \\
\hline \multirow[t]{2}{*}{ Nitrate $(\mu \mathrm{mol} / \mathrm{L})$} & Rainy & 1.200 & 0.336 & 0.400 & 0.865 & \multirow{2}{*}{18.492} & \multirow{2}{*}{$<0.001$} \\
\hline & Dry & 1.341 & 0.298 & 0.826 & 0.572 & & \\
\hline \multirow[t]{2}{*}{ Nitrite $(\mu \mathrm{mol} / \mathrm{L})$} & Rainy & 1.887 & 0.193 & 10.254 & 0.001 & \multirow{2}{*}{5.435} & \multirow{2}{*}{0.023} \\
\hline & Dry & 1.881 & 0.194 & 1.134 & 0.400 & & \\
\hline \multirow[t]{2}{*}{ Total phosphorus $(\mu \mathrm{mol} / \mathrm{L})$} & Rainy & 9.802 & 0.003 & 3.515 & 0.030 & \multirow{2}{*}{19.963} & \multirow{2}{*}{$<0.001$} \\
\hline & Dry & 0.275 & 0.767 & 1.103 & 0.415 & & \\
\hline \multirow{2}{*}{$\begin{array}{l}\text { Total dissolved phosphorus } \\
(\mu \mathrm{mol} / \mathrm{L})\end{array}$} & Rainy & 0.787 & 0.519 & 9.367 & 0.001 & 50263 & \\
\hline & Dry & 3.677 & 0.056 & 3.392 & 0.034 & 50.263 & $<0.001$ \\
\hline Ortophosphate $(\mu \mathrm{mol} / \mathrm{L})$ & Rainy & 0.391 & 0.689 & 0.609 & 0.721 & & \\
\hline & Dry & 1.200 & 0.336 & 0.571 & 0.747 & 0.086 & 0.769 \\
\hline
\end{tabular}

of nutrients at greater depths (Tundisi et al. 1984, Esteves et al. 1994). Pivato et al. (2006) found chemical stratification accompanied by thermal stratification in the Corumbá reservoir in Central-Western Brazil, with lower dissolved oxygen values at greater depths. In Lake Caracaranã, thermal stratification occurred in the rainy season, whereas the water column was homogeneous in the dry season. The clinograde profile in this lake may likewise be associated with thermal stratification.

The low $\mathrm{pH}$ values recorded in Lake Caracaranã corroborate findings on waters in ecosystems in the state of Roraima (Menezes, unpublished data), other areas of the Amazon (Sioli 1991, Panosso \& Kubrusly 2000) and other regions of the country (Espíndola et al. 1996, Dellamano-Oliveira et al. 2003). These values are associated with the acidic characteristics of the soils in savanna areas, decomposition of aquatic macrophytes (which release organic acids) and geochemical characteristics of the region.

The low conductivity values associated with low turbidity indicate that the waters of Lake Caracaranã have good quality. These results are similar to those described by other authors for different ecosystems in the Amazon and a savannah region in Brazil (Panosso \& Kubrusly 2000, Pivato et al. 2006).

Lake Caracaranã has low nutrient values due to the fact that it drains relatively nutrientpoor terrains, particularly tertiary sediments from the Boa Vista Formation that make up the drainage basin of this lake (Filho et al. 1997). The low concentration of nutrients was 


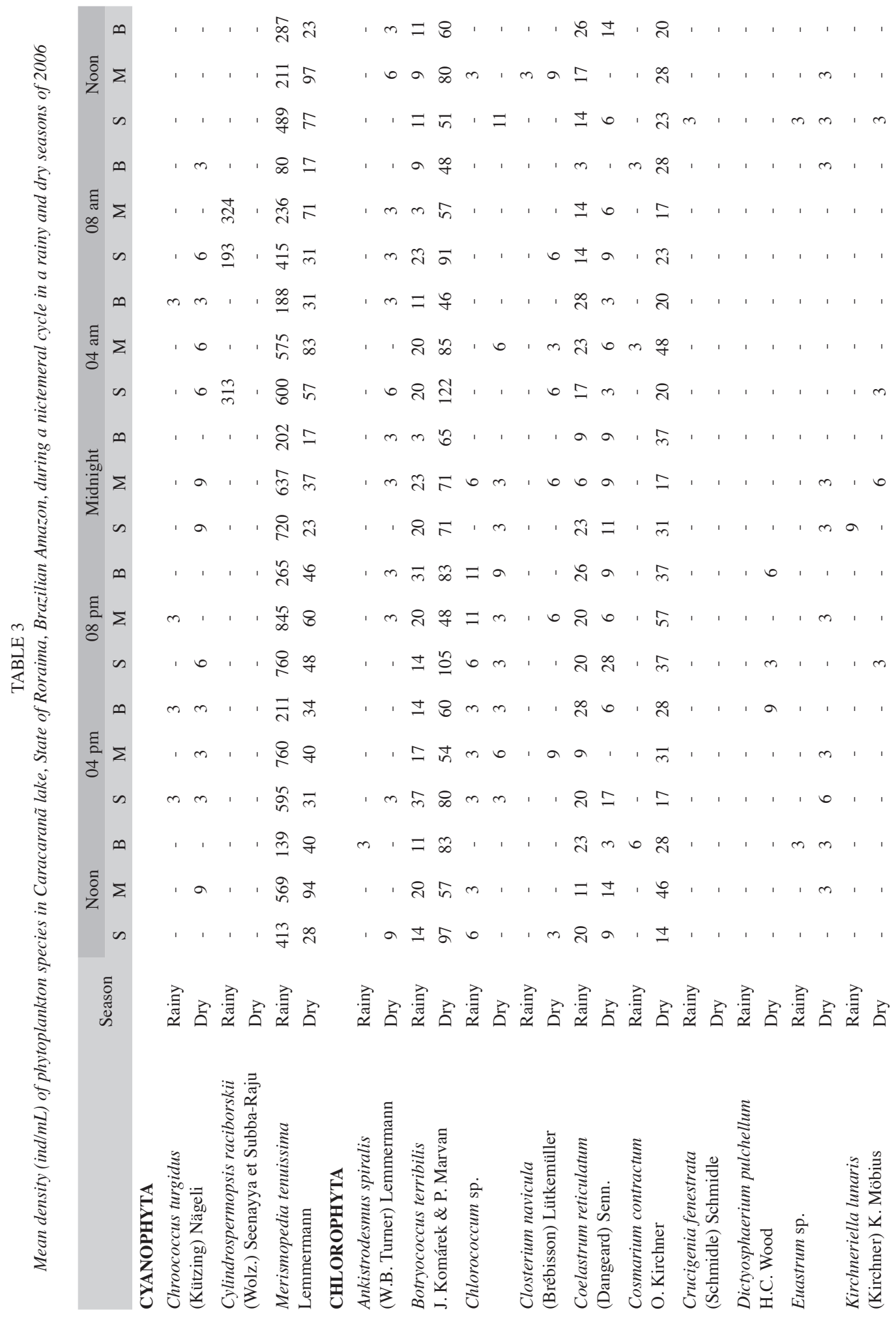




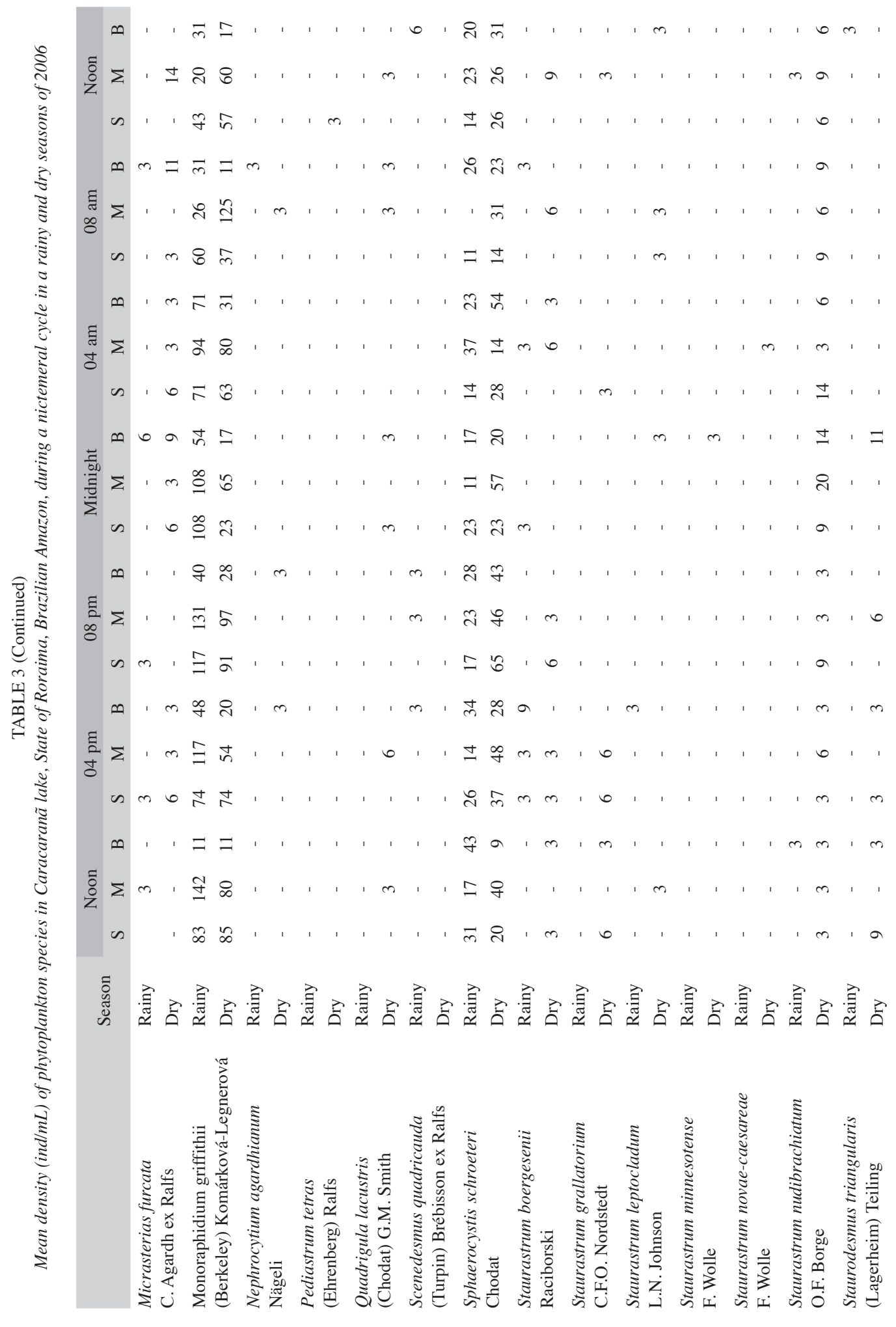




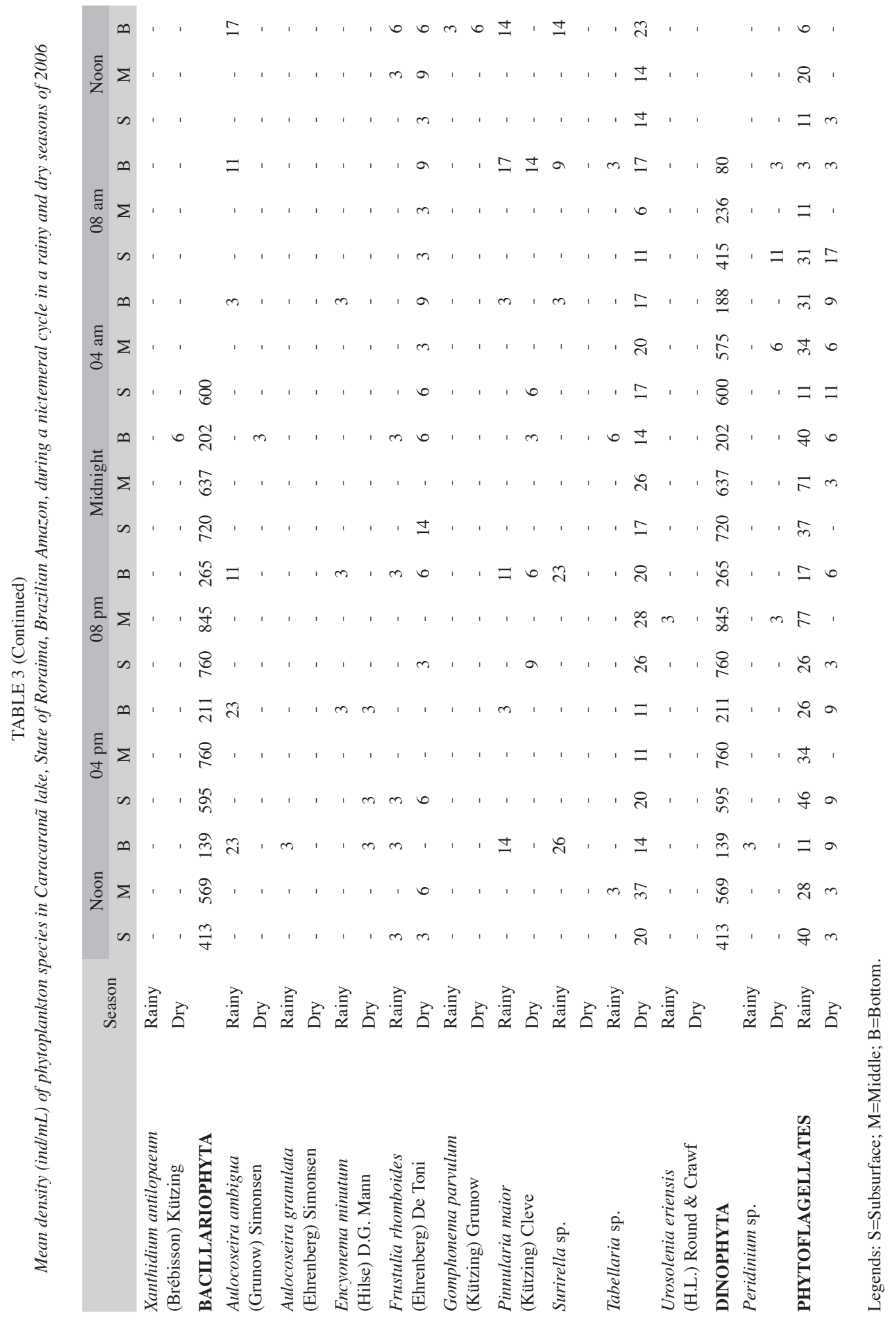


TABLE 4

Canonical coefficients and intra-set correlation of the environmental variables of the CCA first two axes performed in the Caracaranã lake-State of Roraima, Brazilian Amazon

\begin{tabular}{|c|c|c|c|c|}
\hline & & & Axis 1 & Axis 2 \\
\hline Eigenvalue & & & 0.408 & 0.144 \\
\hline Variance percentage explained & & & 40.1 & 14.1 \\
\hline Variance percentage accumulated & & & 40.1 & 54.2 \\
\hline Pearson correlation (species-environment) & & & 0.951 & 0.706 \\
\hline \multicolumn{5}{|l|}{ Monte Carlo test } \\
\hline Eigenvalues - $p$ & & & 0.01 & 0.04 \\
\hline \multirow[t]{3}{*}{ Correlation species-environment } & & & 0.01 & 0.02 \\
\hline & \multicolumn{2}{|c|}{ Canonical coefficient } & \multicolumn{2}{|c|}{ Intra-set correlation } \\
\hline & Axis 1 & Axis 2 & Axis 1 & Axis 2 \\
\hline Water temperature & 0.230 & -0.017 & 0.279 & 0.145 \\
\hline Dissolved oxygen & -0.049 & 0.601 & -0.686 & 0.497 \\
\hline Conductivity & 0.268 & -0.194 & 0.823 & -0.153 \\
\hline $\mathrm{pH}$ & -0.181 & -0.101 & -0.666 & 0.033 \\
\hline Turbidity & 0.037 & -0.040 & 0.650 & -0.332 \\
\hline Total nitrogen & 0.034 & -0.178 & 0.257 & -0.438 \\
\hline Nitrate & -0.078 & -0.205 & -0.558 & -0.026 \\
\hline Nitrite & 0.066 & 0.256 & 0.327 & 0.519 \\
\hline Total phosphorus & -0.325 & -0.618 & -0.685 & -0.589 \\
\hline Total dissolved phosphorus & 0.355 & -0.069 & 0.677 & -0.461 \\
\hline Orthophosphate & -0.005 & -0.237 & -0.026 & -0.217 \\
\hline
\end{tabular}

confirmed by the Trophic State Index calculated for the two circadian cycles.

The composition of species found in Lake Caracaranã and the greater number of taxa from the Chlorophyta division are similar to findings reported in previous studies on Brazilian lakes (Huszar 1996a; Nogueira \& Leandro-Rodrigues 1999; Oliveira \& Calheiros 2000; Nabout et al. 2006). All of these surveys found have a high diversity of Chlorophyta. In Amazon waters, desmids are considered an important group due to the acidic conditions of the waters (Huszar 1996b, 2000, Keppeler et al . 1999a, 1999b).

Nabout et al. (2006) identified 292 species of algae in 21 lakes on the flood plains of the Araguaia River, with Chlorophyceae as the dominant group. Melo et al. (2004) recorded 108 phytoplankton taxa for the Batata and Mussurá Lakes of the Brazilian Amazon. In
Lake Caracaranã, the number of phytoplankton taxa was lower than that described in the studies cited above, but comparable to values described by Espíndola et al. (1996) in the Pantanal wetlands of Brazil (83 taxa) as well as values described by Diaz et al. (1998) in Argentine lakes (40 taxa); in these studies, sampling efforts were greater, carried out over a period of one year and 11 months, respectively. The number of taxa was also similar to that described by Pivato et al. (2006) in an aquatic environment in a savanna region in Brazil (58 taxa), with nicthemeral collections in two seasonal periods, as in the present study.

The low densities of phytoplankton, homogeneity in the distribution of algae among the time of the day and a vertical and seasonal variations observed in Lake Caracaranã are the results of the oligotrophic condition of the system. Melo et al. (2004) report low 

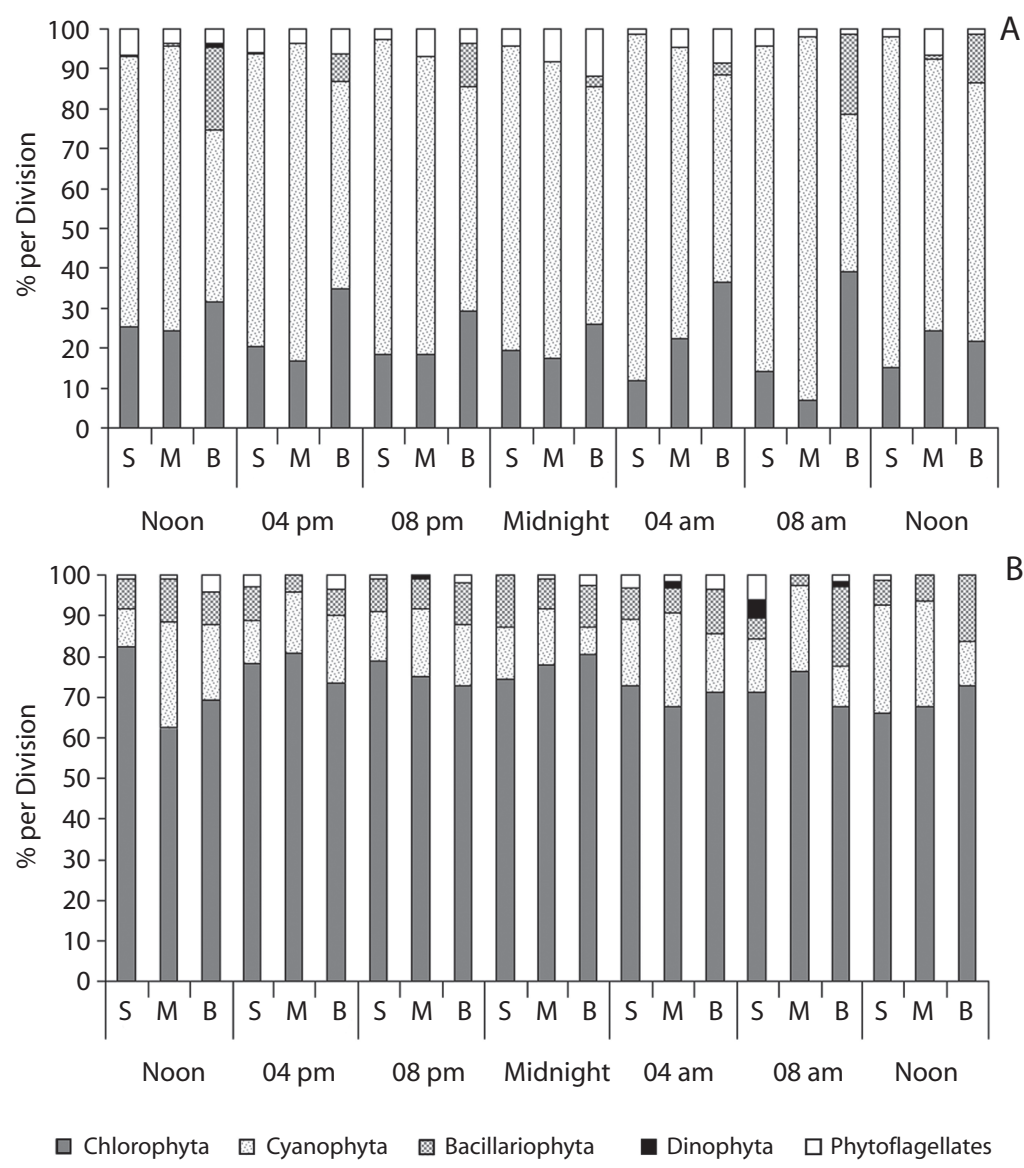

Fig. 1. Diel variation in phytoplankton density (\%) in Lake Caracaranã, state of Roraima, Brazil (A:rainy season 2006; B:dry season 2006; $\mathrm{S}=$ subsurface, $\mathrm{M}=$ Middle, $\mathrm{B}=\mathrm{Bottom})$.

phytoplankton densities for Amazon lakes. Occasional, limited blooms occurred, with densities of Botryococcus terribilis, Cylindrospermopsis raciborskii, Merismopedia tenuissima and Monoraphidium griffithii had densities greater than $100 \mathrm{ind} / \mathrm{mL}$ in at least one sampling unit. Based on CCA, the high density of Chlorophyta was attributed to higher $\mathrm{pH}$ values and concentrations of dissolved oxygen, total phosphorus and nitrate. The greater density of $M$. tenuissima is explained by higher conductivity and turbidity values as well as concentrations of total dissolved phosphorus, whereas the occurrence of $C$. raciborskii was associated with oxygenated layers of water in the rainy season.

Lake Caracaranã is a typical oligotrophic Amazonian lake, with low species richness and low algae densities. Knowledge on the phytoplankton in this lake contributes toward knowledge on algal diversity in a lake located on an indigenous reservation in the Brazilian Amazon. The occurrence of potentially toxic algae, such as $C$. raciborskii, does not indicate that the lake is undergoing a process of eutrophication, but monitoring is necessary in order to avoid future blooms. The occurrence of this species is the result of the shallow 


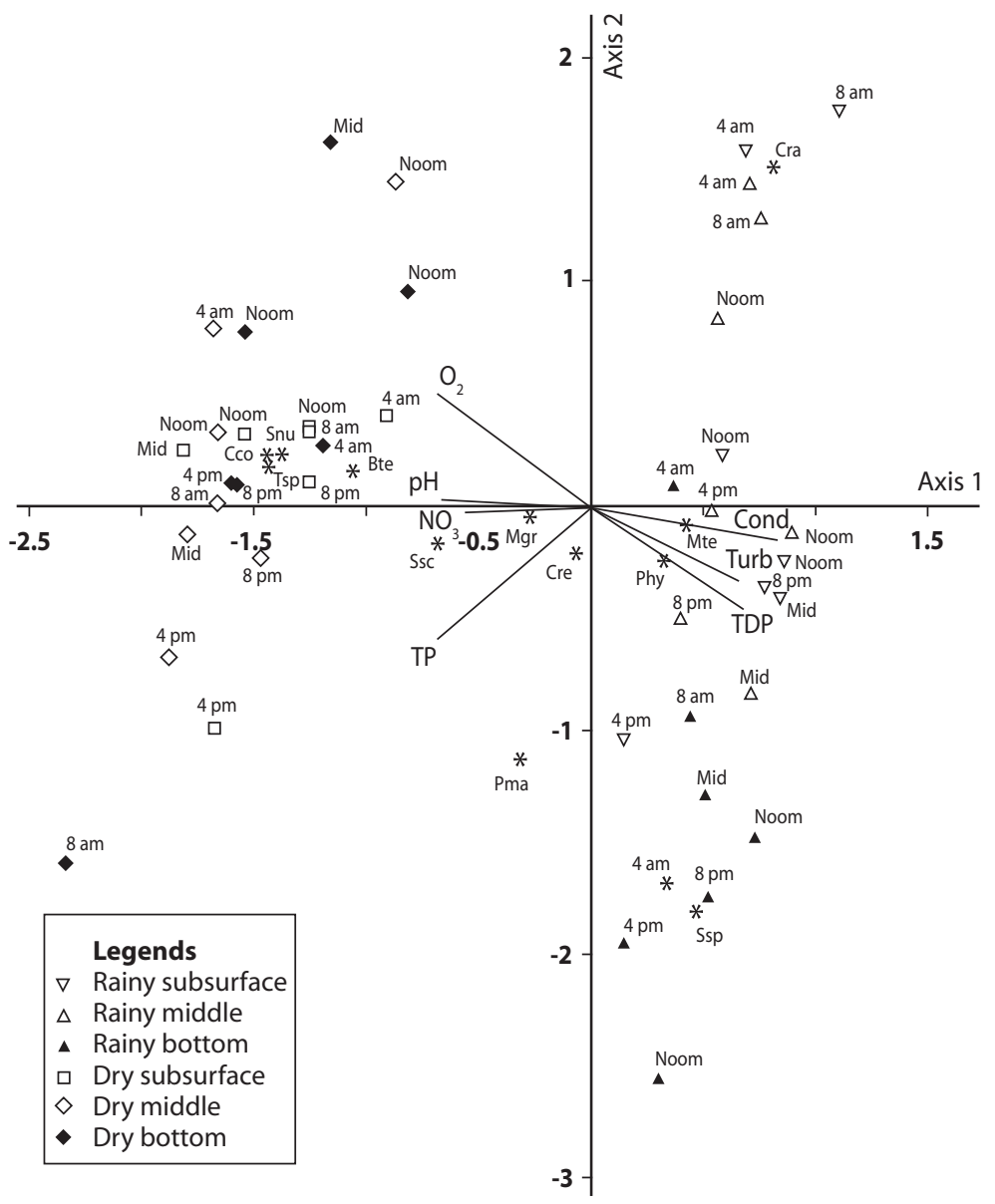

Fig. 2. Canonical correspondence analysis plot (CCA) of samples showing the correspondence of taxonomic composition and abiotic variables in Lake Caracaranã, Brazil. The units are identified based on times of the day (12 pm, 4 pm, 8 pm, 12 am, 4 am, 8 am and $12 \mathrm{pm}$ ); symbols indicate season (dry, rainy) and sampling depths (subsurface, middle of water column bottom). (Abbreviations: $\mathrm{TP}=$ water temperature; $\mathrm{pH}=\mathrm{pH} ; \mathrm{O}_{2}=$ dissolved oxygen; Turb=turbidity; Cond=conductivity; $\mathrm{NO}_{3}=$ nitrate and TDP=total dissolved phosphorus; Abundant taxa: Aam=Aulacoseira ambigua $;$ Bte=Botryococcus terribilis; $\mathrm{Cco}=$ Cosmarium contractum; $\mathrm{Cra}=$ Cylindrospermopsis raciborskii; $\mathrm{Cre}=$ Coelastrum reticulatum; Mgr=Monoraphidium griffithii; Mte=Merismopedia tenuissima; Phy=Phytoflagellates; Pma= Pinnularia maior; Snu=Staurastrum nudibrachiatum; $\mathrm{Ssc}=$ Sphaerocystis schroeteri; $\mathrm{Ssp}=$ Surirella $\mathrm{sp} . ;$ Tsp=Tabellaria $\mathrm{sp}$.).

depth of Lake Caracaranã as well as its high temperatures and availability of light. Despite the occurrence of taxa that indicate organic pollution, the biomass and frequency of these taxa indicate that the system is not currently threatened.

\section{ACKNOWLEDGMENTS}

The authors are grateful to the Brazilian fostering agency Coordenação de Aperfeiçoamento de Pessoal do Ensino Superior (CAPES - PQI 42). 


\section{RESUMEN}

Los sistemas de lagos naturales constituyen reservorios importantes para el abastecimiento de agua residencial, la producción de peces, actividades recreativas y el disfrute de su belleza natural. Sin embargo, el impacto humano puede afectar su estado de salud como resultado de la degradación y la pérdida de biodiversidad. El objetivo del estudio fue determinar el estado de salud de un lago natural en una reserva indígena de la Amazonia brasileña, usando los cambios de la comunidad fitoplanctónica a lo largo de la época lluviosa (junio) y seca (de noviembre) en 2006. Se recogieron muestras de agua (temperatura, $\mathrm{pH}$, conductividad y profundidad de Secchi) y fitoplancton del subsuelo, columna media del agua y a $30 \mathrm{~cm}$ por encima del fondo, cada 24horas, en una estación central en el lago. Las variables bióticas y abióticas se correlacionaron mediante análisis de correspondencia canónica (CCA). Los resultados mostraron que el lago exhibió altas temperaturas en ambas temporadas, una estratificación térmica solamente durante la época lluviosa así como un patrón vertical de oxígeno disuelto, mientras que en la estación seca se observó una alta cantidad de oxígeno en el hipolimnion. En la época lluviosa, el agua cercana al fondo era ácida, turbia y tenía una mayor concentración de fósforo. Oxígeno disuelto, conductividad, $\mathrm{pH}$, nitritos, fósforo total y disuelto mostraron variaciones diarias en la época lluviosa, mientras que la temperatura del agua, oxígeno disuelto, nitrógeno total y fósforo disuelto mostraron una diferencia significativa en las horas del día durante la estación seca. El fitoplancton estuvo representado por 39 táxones, y Chlorophyta mostró la mayor riqueza de especies, un total de 25 táxones. En Chlorophyta, los desmidios fueron los más diversos, lo que representa el 52\%. Bacillariophyta (nueve especies) fue el segundo grupo más diverso. En Cyanophyta se encontraron tres especies, incluyendo Merismopedia tenuissima, el taxon más abundante. A pesar de la ocurrencia de táxones que indican contaminación orgánica, la biomasa y frecuencia sugieren que el sistema actualmente no está en peligro. Lago Caracaranã es un sistema oligotrófico, con baja densidad de algas y aislados episodios de afloramiento debido a su poca profundidad.

Palabras clave: Chlorophyta, Cyanophyta, variación diaria, sistema oligotrófico, variación estacional, lago tropical, Brasil.

\section{REFERENCES}

Dellamano-Oliveira, M.J., P.A.C. Senna \& G.M. Taniguchi. 2003. Limnological characteristics and seasonal changes in density and diversity of the phytoplanktonic community at the Caçó-Pond, Maranhão State, Brazil. Arch. Biol. Technol. 46: 641-651.
Diaz, M.M., F.L. Pedroso \& P.F. Temporetti. 1998. Phytoplankton of two Araucanian lakes of differing trophic status (Argentina). Hydrobiologia 369/370: 45-57.

Domitrovic, Y.Z. 2003. Effect of fluctuations in water level on phytoplankton development in three lakes of the Paraná River floodplain (Argentina). Hydrobiologia 510: 175-193.

Espíndola, E.G., T. Matsumura-Tundisi \& I.D. Moreno. 1996. Estrutura da comunidade fitoplanctônica da lagoa Albuquerque (Pantanal Matogrossense), Mato Grosso do Sul, Brasil. Acta Limnol. Bras. 8: 13-37.

Esteves, F.A., S.M. Thomaz \& F. Roland. 1994. Comparison of the metabolism of two floodplain lakes of the Trombetas River (Pará, Brazil) based on study of diel variation. Amazoniana 13: 33-46.

Filho, F.S., B. Turcq, A.C. Filho \& A.G. Souza. 1997. Registros sedimentares de lagos e brejos dos campos de Roraima: implicações paleoambientais ao longo do Holoceno, p.295-305. In R.I. Barbosa, E.J.G. Ferreira \& E.G. Castellón (eds.). Homem, Ambiente e Ecologia no Estado de Roraima. Manaus, INPA, Brasil.

Golterman, H.L., R.S. Clymo \& M.Am Ohnstad. 1978. Methods or physical and chemical analysis of freshwater. IBP Handbook $\mathrm{N}^{\circ} 8$ Blackwell, Oxford, England.

Grönblad, R. 1945. De algis brasiliensisbus praecipue desmidiales, in regione inferiors, fluminis Amazonas e professore August Ginberger (Wien) MCMXVII collectis. Acta Soc. Sci. Fenn. Ser. B 2: 1-43.

Huszar, V.L.M. 1996a. Floristic composition and biogeographical aspects of phytoplankton of an Amazonian floodplain lake (Lago Batata, Pará, Brasil). Acta Limnol. Bras. 8: 127-136.

Huszar, V.L.M. 1996b. Planktonic algae other than desmids, of three Amazonian Systems Lake (Lake Batata, Lake Mussurá and Trombetas River), Pará, Brazil. Amazoniana 14: 37-73.

Huszar,V.L.M. \& C.S. Reynolds. 1997. Phytoplankton periodicity and sequences of dominance in an Amazonian flood-plain lake (Lago Batata, Pará, Brasil): responses to gradual environmental change. Hydrobiologia 346: 169-181.

Huszar,V.L.M., L. Silva, P. Domingos, M. Marinho \& S. Melo. 1998. Phytoplankton species composition is more sensitive than OECD criteria to the trophic status of three Brazilian tropical lakes. Hydrobiologia 369/370: 59-72. 
Huszar, V.L.M. 2000. Fitoplâncton, p. 91-104. In R.L Bozelli, F.A. Esteves \& F. Roland (eds.). Lago Batata: impacto e recuperação de um ecossistema amazônico. Rio de Janeiro, UFRJ/SBL, Brasil.

Ibañez, M.S.R. 1998. Phytoplankton composition and abundance of a central Amazonian floodplain lake. Hydrobiologia 362: 78-83.

Izaguirre, I., I. O'Farrell \& G. Tell. 2001. Variation in phytoplankton composition and limnological features in a water-water ecotone of the Lower Paraná Basin (Argentina). Freshw. Biol. 46: 63-74.

Kangurt, K., T. Mols, A. Milius \& R. Laugaste. 2003 Phytoplankton response to changed nutrient level in Lake Peipsi (Estonia) in 1992-2001. Hydrobiologia 506-509: 265-272.

Keppeler, E.C., M.R.M. Lopes \& C.S. Lima. 1999a. Ficoflórula do lago Amapá em Rio Branco-Acre, I: Euglenophyceae. Rev. Bras. Biol. 59: 679-686.

Keppeler, E.C., M.R.M. Lopes \& C.S. Lima. 1999b. Ficoflórula do lago Amapá em Rio Branco-Acre, II: Chlorophyta. Rev. Bras. Biol. 59: 687-691.

Komárková, J. \& R. Tavera. 2003. Steady state of phytoplankton assemblage in the tropical Lake Catemaco (Mexico). Hydrobiologia 502: 187-196.

Kratzer, C.R. \& P.L. Brezonik. 1981 A Carlson type trophic state index for nitrogen in Florida lakes. Water Resour. Bull. 17: 713-714.

Kristiansen, J. \& M. Menezes. 1998. Silica-scaled Chrysophytes from an Amazonian floodplain lake, Mussará Lake, northern Brazil. Algol. Stud. 90: 97-118.

Lobo, E.A. \& G. Leighton. 1986. Estruturas comunitárias de las fitocenosis planctónicas de los sistemas de desembocaduras de ríos y esteros de la zona central de Chile. Rev. Biol. Mar. 22: 1-29.

Lopes, M.R.M. \& C.E.M. Bicudo. 2003. Desmidioflórula de um lago da planície de inundação do Rio Acre, Estado do Amazonas, Brasil. Acta Amazon. 33: 167-212.

Maberly, S.C., L. King, M.M. Dent, R.I. Jones \& C.E. Gibson. 2002. Nutrient limitation of phytoplankton and periphyton growth in upland lakes. Freshw. Biol. 47: 2136-2152.

Mackereth, F.J.H., J. Heron \& J.F. Talling. 1978. Water analysis: some revised methods for limnologists. Kendall, Titus Wilson \& Son Ltd (Freshwater Biological Association. Scientific Publication $\mathrm{N}^{\circ} 36$ ).
McCune, B. \& M.J. Mefford. 1999. PC-ORD for Windows. Multivariate Analysis of Ecological Data. MjM Software, Gleneden Beach, Oregon, USA.

Melo, S., V.L.M. Huszar, F. Roland, F.A. Esteves \& R. Bozelli. 2004. Phytoplankton diel variation and vertical distribution in two Amazonian floodplain lakes (Batata Lake and Mussurá Lake, Pará-Brasil) with different mixing regimes. Amazoniana 18: 1-10.

Menezes, M., C.G. Fonseca \& E.P. Nascimento. 1995. Algas de três ambientes de águas claras do Município de Parintins, Estado do Amazonas, Brasil: Euglenophyceae e Dinophyceae. Hoehnea 22: 1-15.

Nabout, J.C., I.S. Nogueira \& L.G. Oliveira. 2006. Phytoplankton community of floodplain lakes of the Araguaia River, Brazil, in the rainy and dry seasons. J. Plankton Res. 28: 181-193.

Nogueira, I.S. \& N.C. Leandro-Rodrigues. 1999. Algas planctônicas de um lago artificial do Jardim Botânico Chico Mendes, Goiânia, Goiás: Florística e algumas considerações ecológicas. Rev. Bras. Biol. 59: $377-$ 395 .

Oliveira, M.D. \& D.F. Calheiros. 2000. Flood pulse influence on phytoplankton communities of the south Pantanal floodplain, Brazil. Hydrobiologia 427: 101112.

Panosso, R. \& L. Kubrusly. 2000. Avaliação espacial e temporal das variáveis limnológicas básicas e nutrientes, p. 57-71. In R.L. Bozelli, F.A. Esteves \& F. Roland (eds.). Lago Batata: impacto e recuperação de um ecossistema amazônico. Rio de Janeiro, UFRJ/SBL, Brazil.

Pinilla, G.A. 2006. Vertical distribution of phytoplankton in a clear water lake of Colombian Amazon (Lake Boa, Middle Caquetá). Hydrobiologia 568: 79-90.

Pivato, M.B., S. Train \& L.C. Rodrigues. 2006. Dinâmica nictemeral das assembléias fitoplanctônicas em um reservatório tropical (reservatório de Corumbá, Estado de Goiás, Brasil), em dois períodos do ciclo hidrológico. Acta Sci. Biol. Sci. 28: 19-29.

Reynolds, C.S. 1998. What factors influence the species composition of phytoplankton in lakes of different trophic status? Hydrobiologia 369/370: 11-26.

Reynolds, C.S., V. Huszar, C. Kruk, L. Naselli-Flores \& S. Melo. 2002. Towards a functional classification of the freshwater phytoplankton. J. Plankton Res. 24: 417-428.

Rodrigo, M.A., C. Rojo \& L.X. Armengol. 2003. Plankton biodiversity in a landscape of shallow water bodies 
(Mediterranean coast, Spain). Hydrobiologia 506509: 317-326.

Roland, F. 2000. Produção primária fitoplanctônica, p.107117. In R.L. Bozelli, F.A. Esteves \& F. Roland (eds.). Lago Batata: impacto e recuperação de um ecossistema amazônico. Rio de Janeiro: UFRJ/SBL, Brasil.

Roozen, F.C.J.M., G.J. Van Geest, B.W. Ibelings, R. Roijackers, M. Scheffer \& A.D. Buijse. 2003. Lake age and water level affect the turbidity of floodplain lakes along the lower Rhine. Freshw. Biol. 48: 519-531.

Roraima Environment and Technology Foundation. 1994. Roraima: O Brasil do hemisfério norte. Boa Vista, AMBTEC, Brasil.

Schagerl, M. \& S.O. Oduor. 2003. On the limnology of Lake Baringo (Kenya): II. Pelagic primary production and algal composition of Lake Baringo, Kenya. Hydrobiologia 506-509: 297-303.

Schemel, L.E., T.R. Sommer, A.B. Muller-Solger \& W. Harrell. 2004. Hydrologic variability, water chemistry, and phytoplankton biomass in a large floodplain of the Sacramento River, CA, USA. Hydrobiologia 513: 129-139.

Shannon, C.E. \& W. Weaver. 1963. The mathematical theory of communication. Urbana, Illinois University, USA.

Sioli, H. 1991. Amazônia - Fundamentos da Ecologia da Maior Região de Florestas Tropicais. Petrópolis, Vozes, Brasil.

Sophia, M.G. \& I.C.A. Dias. 1996. Algas de três ambientes de águas claras do Município de Parintins, Estado do Amazonas, Brasil: Oedogoniophyceae. Hoehnea 23: 59-80.

Sophia, M.G. \& V.L.M. Huszar. 1996. Planktonic desmids of three Amazonian systems (Lake Batata, Lake Mussurá and Trombetas river), Pará, Brazil. Amazoniana 14: 75-90.
Souza, K.F., S. Melo \& F.F. Almeida. 2007. Desmídias de um lago de inundação do Parque Nacional do Jaú (Amazonas - Brasil). Ver. Brasil. Bioc. 5: 24-26.

Strickland, J.D. \& T.R. Parsons. 1965. A manual of sea water analysis. Bull. Fish. Res. B. Can. 125: 1-185.

Takano, K., Y. Ishikawa, H. Mikami, S. Ban, T. Yoshida, T. Aono, K. Imada, R. Yasutomi, K. TakeuchI \& S. Hino. 2001. Analysis of the change in dominant phytoplankton species in unstratified Lake OshimaOhnuma estimated by a bottle incubation experiment. Limnology 2: 29-35.

Toledo Jr., A.P., M. Talarico, S.J. Chinez \& E.G. Agudo. 1983. A aplicação de modelos simplificados para a avaliação de processo da eutrofização em lagos e reservatórios tropicais, p. 1-34. In Anais do Congresso Brasileiro de Engenharia Sanitária e Ambiental, Camboriú, SC, Brasil.

Tundisi, J.G., B.R. Forsberg, A.H. Devol, T.M. Zaret, T.M. Tundisi, A. Santos, J.S. Ribeiro \& E.R. Hardy. 1984. Mixing patterns in Amazon lakes. Hydrobiologia 108: 3-15.

Utermöhl, H. 1958. Zur vervollkommer der quantitativen phytoplankton methodik. Mitt. Int. Ver. Theor. Angew. Limnol. 9: 1-38.

Valderrama, G.C. 1981. The simultaneous analysis of total nitrogen and total phosphorus in natural waters. Mar Chem. 10: 109-122.

Villafaiñe, V.E. \& F.M.H. Reid. 1995. Métodos de Microscopía para la Cuantificación del Fitoplancton. In $\mathrm{K}$. Alveal, M.E. Ferraro, E.C. Oliveira \& E. Sar (eds.). Manual de Métodos Ficológicos. Universidad de Concepción, Chile.

Walks, D.J. \& H. Cyr. 2004. Movement of plankton through lake-stream systems. Freshw. Biol. 49: 745-759. 